\title{
The Effectiveness of a Rehabilitative Exercise Program on Mechanical Sensory Receptors Development after Surgical Intervention for Knee Cartilage Injury within Handball and Boxing Players
}

\author{
Hussam-Eldin Nabih Abdulfatah Yousuf', Mustafa Abdulaziz Qukqila ${ }^{2}$, Amr Alpadry \\ Mohamadin $^{3}$ \\ ${ }^{1}$ Assistant professor, Curricula and physical education teaching methods department, Faculty of physical education, Al-Azhar \\ university, Egypt \\ ${ }^{2}$ Lecturer, sport health sciences department, Faculty of physical education, Al-Azhar university, Egypt \\ ${ }^{3}$ Deputized lecturer, Faculty of physical education, Al-Azhar university, Egypt
}

\begin{abstract}
This research aims at designing exercise rehabilitation program for mechanical sensory receptors development after surgical intervention for knee cartilage injury within students of Faculty of physical education, Al-Azhar University, and identify its effect on developing lower limb's mechanical sensory receptors, injured knee joint range of motion, working muscle strength on injured knee joint, real balance for injured limb. Five (5) students from faculty of physical education, aged between 18-20 years, who have knee cartilage entire cut, participated in the study. Results indicate that the proposed rehabilitative program has a positive effect on mechanical sensory receptors, range of motion, muscle strength and balance variables.
\end{abstract}

Keywords: knee cartilage injury, rehabilitative program

Introduction and problem of the research:

ports injuries lead to shortage in the motor system negatively whether through nonparticipation or decrease in performance level (Yehia, M. \& Zaghlol. I., 2004).

Joints injuries are considered important injuries sportsmen face and they affect their motor performance greatly because the basic skills and physical requirements of any sport depend mainly on joints (Abdelfattah, H. N., 2007).

Abdelazeem Alawadly mentions that the knee joint with its bony and muscular components is one of the most sports joints subject to injuries (Alawadly, A., 2006).

The knee is subject to injuries especially during competitions in fractions sports because of its location between two bones in addition to the weight it carries (Bakry, M. K., 2000).

Osama Ryad says that the injury in this joint is the most common one among athletes and in all kinds of physical practices (Ryad, O. \& Abdelraheem, N., 2001).
Knee joint is of the most complicated human body joints. It is a one-direction joint, functionally involved with hip and ankle joints in closed kinetic chain to support body weight setting, getting up and all motor activities, it is also involved in open kinetic chain during movement in space (Briggs, Sandor \& Keninan, 1995).

Knee cartilage injuries are about a third of total injuries suffered by athletes, where treatment options include (rehabilitation without surgery, cartilage chondrectomy, chondroplasty or replacement (Harner \&Navarro, 1998).

Sensory reception weakness increases incidence of injuries, so sensory reception rehabilitation works on lowing incidence of sports injuries and to improve rehabilitation programs results (Kaminski, 2003)

Sensory reception training should be at beginning of therapeutic exercise programs through coordination and balance exercises. All rehabilitation programs emphasizes the need for sensory reception development (Lupescu, Acsinte, Alexandru \&Milon, 2010).

Through what presented above, this research's problem emerged as a scientific attempt to design rehabilitative 
exercise program for mechanical sensory receptors development after surgical intervention for knee cartilage injury.

This research aims at designing exercise rehabilitation program for mechanical sensory receptors development after surgical projection intervention for knee cartilage injury within students of Faculty of physical education, Al-Azhar University, and identify its effect on developing lower limb's mechanical sensory receptors, injured knee joint range of motion, working muscle strength on injured knee joint, real balance for injured limb.

This research works to test the following hypotheses:

1- There are significant differences between pre and post measurement for mechanical sensory receptors variable towards post measurement.

2- There are significant differences between pre and post measurement for range of motion variable towards post measurement.

3- There are significant differences between pre and post measurement for working muscle strength on injured knee joint variable towards post measurement.
4- There are significant differences between pre and post measurement for balance variable towards post measurement.

\section{Methods}

Five (5) students from faculty of physical education, aged between 18-20 years, who have knee cartilage entire cut, participated in the study.

The researchers, through scientific reference scan, prepared a questionnaire to get experts' opinion about the proposed rehabilitative exercise program, based on exerts' opinion, the program period determined by 6 weeks in three phases. The phase lasted for two weeks.

Pilot study conducted during the period from Sunday, $10 / 1 / 2016$ to Thursday, 14/01/2016, pre measurement for research variables individually conducted during the period from Wednesday, 20/1/2016 to Sunday, 24/01/2016. The proposed rehabilitative exercise program implemented with five training sessions per week for six weeks, post measurement for research variables individually conducted during the period from Sunday, 13/3/2016 to Monday, 14/03/2016.

\section{Results:}

Table (1)

Significance of differences between pre measurement for injured and uninjured knees in research variables

\begin{tabular}{|c|c|c|c|c|c|c|c|}
\hline \multirow[b]{2}{*}{$\mathrm{S}$} & \multirow[b]{2}{*}{ Variables } & \multicolumn{2}{|c|}{ Uninjured knee } & \multicolumn{2}{|c|}{ Injured knee } & \multirow[b]{2}{*}{ "Z" } & \multirow[b]{2}{*}{ Significance } \\
\hline & & $\begin{array}{c}\text { Mean } \\
\text { rank }\end{array}$ & $\begin{array}{c}\text { Sum of } \\
\text { ranks }\end{array}$ & $\begin{array}{c}\text { Mean } \\
\text { rank }\end{array}$ & $\begin{array}{c}\text { Sum of } \\
\text { ranks }\end{array}$ & & \\
\hline 1 & Front muscles strength. & 8.00 & 40.00 & 3.00 & 15.00 & -2.627 & 0,009 \\
\hline 2 & Back muscle strength. & 8.00 & 40.00 & 3.00 & 15.00 & -2.611 & 0,009 \\
\hline 3 & Range of motion. (flexion) & 8.00 & 40.00 & 3.00 & 15.00 & -2.611 & 0,009 \\
\hline 4 & Range of motion (Extension). & 3.00 & 15.00 & 8.00 & 40.00 & -2.652 & 0,008 \\
\hline 5 & Balance & 3.00 & 15.00 & 8.00 & 40.00 & -2.611 & 0,009 \\
\hline 6 & Sensory receptors. & 3.00 & 15.00 & 8.00 & 40.00 & -2.611 & 0,009 \\
\hline
\end{tabular}

$* \mathrm{Z}$ significance at 0.05 level $=1.96$ 
Table (2)

Significance of differences between pre and post measurement for injured knee in research variables

\begin{tabular}{|c|c|c|c|c|c|c|c|}
\hline \multirow{2}{*}{$\mathrm{S}$} & \multirow{2}{*}{ variables } & \multicolumn{2}{|c|}{ Mean rank } & \multicolumn{2}{|c|}{ Sum of ranks } & \multirow{2}{*}{ "Z" } & \multirow{2}{*}{ Significance } \\
\hline & & + & - & + & - & & \\
\hline 1 & Front muscles strength. & 0.00 & 3.00 & 0.00 & 15.00 & -2.060 & 0,039 \\
\hline 2 & Back muscle strength. & 0.00 & 3.00 & 0.00 & 15.00 & -2.023 & 0,043 \\
\hline 3 & Range of motion. (flexion) & 0.00 & 3.00 & 0.00 & 15.00 & -2.023 & 0,043 \\
\hline 4 & Range of motion (Extension). & 3.00 & 0.00 & 15.00 & 0.00 & -2.023 & 0,043 \\
\hline 5 & Balance & 3.00 & 0.00 & 15.00 & 0.00 & -2.023 & 0,043 \\
\hline 6 & Sensory receptors. & 3.00 & 0.00 & 15.00 & 0.00 & -2.023 & 0,043 \\
\hline
\end{tabular}

$* \mathrm{Z}$ significance at 0.05 level $=1.96$

Table (3)

Improvement ratio between pre and post measurement of injured knee in research variables

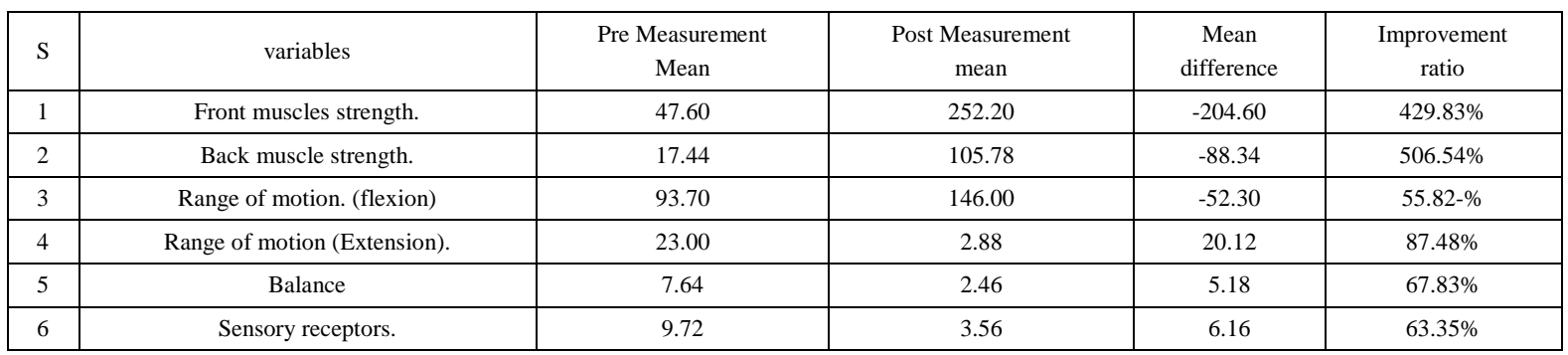

Table (4)

Significance of differences between pre and post measurement for uninjured knee in research variables

\begin{tabular}{|c|c|c|c|c|c|c|c|}
\hline \multirow{2}{*}{ S } & \multirow{2}{*}{ variables } & \multicolumn{2}{|c|}{ Mean rank } & \multicolumn{2}{|c|}{ Sum of ranks } & \multirow{2}{*}{ "Z" } & \multirow{2}{*}{ Significance } \\
\hline & & + & - & + & - & & \\
\hline 1 & Front muscles strength. & 0.00 & 3.00 & 0.00 & 15.00 & -2.023 & 0,043 \\
\hline 2 & Back muscle strength. & 0.00 & 3.00 & 0.00 & 15.00 & -2.023 & 0,043 \\
\hline 3 & Range of motion. (flexion) & 2.50 & 1.00 & 5.00 & 1.00 & -1.069 & 0,285 \\
\hline 4 & Range of motion (Extension). & 2.00 & 2.00 & 4.00 & 2.00 & -0.577 & 0,564 \\
\hline 5 & Balance & 3.50 & 1.00 & 14.00 & 1.00 & -1.753 & 0,080 \\
\hline 6 & Sensory receptors. & 2.67 & 3.50 & 8.00 & 7.00 & -0.135 & 0,893 \\
\hline
\end{tabular}

$* \mathrm{Z}$ significance at 0.05 level $=1.96$

Table (5)

Improvement ratio between pre and post measurement of uninjured knee in research variables

\begin{tabular}{|c|c|c|c|c|c|}
\hline S & variables & $\begin{array}{c}\text { Pre Measurement } \\
\text { mean }\end{array}$ & $\begin{array}{c}\text { Post Measurement } \\
\text { mean }\end{array}$ & Mean & Improvement \\
difference & ratio \\
\hline 1 & Front muscles strength. & 166.20 & 259.80 & -93.60 & $56.32 \%$ \\
\hline 2 & Back muscle strength. & 80.45 & 104.48 & -24.03 & $29.87 \%$ \\
\hline 3 & Range of motion. (flexion) & 145.40 & 144.20 & 1.20 & $0.83 \%$ \\
\hline 4 & Range of motion (Extension). & 2.40 & 2.20 & 0.20 & $8.33 \%$ \\
\hline 5 & Balance & 3.46 & 2.16 & 1.30 & $37.57 \%$ \\
\hline 6 & Sensory receptors. & 3.24 & 3.19 & 0.05 & $1.42 \%$ \\
\hline
\end{tabular}

Table (6)

Significance of differences between post measurement for injured and uninjured knees in research variables 


\begin{tabular}{|c|c|c|c|c|c|c|c|}
\hline \multirow[b]{2}{*}{$\mathrm{S}$} & \multirow[b]{2}{*}{ Variables } & \multicolumn{2}{|c|}{ Uninjured knee } & \multicolumn{2}{|c|}{ Injured knee } & \multirow[b]{2}{*}{ "Z" } & \multirow[b]{2}{*}{ Significance } \\
\hline & & $\begin{array}{l}\text { Mean } \\
\text { Rank }\end{array}$ & $\begin{array}{c}\text { Sum of } \\
\text { ranks }\end{array}$ & $\begin{array}{c}\text { Mean } \\
\text { rank }\end{array}$ & $\begin{array}{c}\text { Sum of } \\
\text { ranks }\end{array}$ & & \\
\hline 1 & Front muscles strength. & 7.10 & 35.50 & 3.90 & 19.50 & -1.676 & 0,094 \\
\hline 2 & Back muscle strength. & 4.20 & 21.00 & 6.80 & 34.00 & -1.358 & 0,175 \\
\hline 3 & Range of motion. (flexion) & 4.10 & 20.50 & 6.90 & 34.50 & -1.485 & 0,138 \\
\hline 4 & Range of motion (Extension). & 4.00 & 20.00 & 7.00 & 35.00 & -1.695 & 0,090 \\
\hline 5 & Balance & 4.00 & 20.00 & 7.00 & 35.00 & 1.586 & 0.113 \\
\hline 6 & Sensory receptors. & 4.00 & 20.00 & 7.00 & 35.00 & -1.567 & 0,117 \\
\hline
\end{tabular}

$* \mathrm{Z}$ significance at 0.05 level $=1.96$

Table (7)

Differences between improvement ratios for injured and uninjured knee in research variables

\begin{tabular}{|c|c|c|c|c|c|c|c|c|}
\hline \multirow[b]{2}{*}{$\mathrm{S}$} & \multirow[b]{2}{*}{ Variables } & \multicolumn{3}{|c|}{ Injured knee } & \multicolumn{3}{|c|}{ Uninjured knee } & \multirow[b]{2}{*}{$\begin{array}{c}\text { Ratio } \\
\text { Difference }\end{array}$} \\
\hline & & $\begin{array}{c}\text { Pre } \\
\text { Measurement } \\
\text { mean }\end{array}$ & $\begin{array}{c}\text { Post } \\
\text { Measurement } \\
\text { mean }\end{array}$ & $\begin{array}{c}\text { Improvement } \\
\text { ratio }\end{array}$ & $\begin{array}{c}\text { Pre } \\
\text { Measurement } \\
\text { mean }\end{array}$ & $\begin{array}{c}\text { Post } \\
\text { Measurement } \\
\text { mean }\end{array}$ & $\begin{array}{l}\text { Improvement } \\
\text { ratio }\end{array}$ & \\
\hline 1 & $\begin{array}{l}\text { Front muscles } \\
\text { strength. }\end{array}$ & 166.20 & 259.80 & $56.32 \%$ & 47.60 & 252.20 & $429.83 \%$ & $373.51 \%$ \\
\hline 2 & $\begin{array}{l}\text { Back muscle } \\
\text { strength. }\end{array}$ & 80.45 & 104.48 & $29.87 \%$ & 17.44 & 105.78 & $506.54 \%$ & $476.67 \%$ \\
\hline 3 & $\begin{array}{l}\text { Range of } \\
\text { motion. } \\
\text { (flexion) }\end{array}$ & 145.40 & 144.20 & $0.83 \%$ & 93.70 & 146.00 & $55.82-\%$ & $56.65 \%$ \\
\hline 4 & $\begin{array}{c}\text { Range of } \\
\text { motion } \\
\text { (Extension). }\end{array}$ & 2.40 & 2.20 & $8.33 \%$ & 23.00 & 2.88 & $87.48 \%$ & $79.15 \%$ \\
\hline 5 & Balance & 3.46 & 2.16 & $37.57 \%$ & 7.46 & 2.46 & $67.83 \%$ & $30.26 \%$ \\
\hline 6 & $\begin{array}{c}\text { Sensory } \\
\text { receptors. }\end{array}$ & 3.24 & 3.19 & $1.42 \%$ & 9.72 & 3.56 & $63.35 \%$ & $61.93 \%$ \\
\hline
\end{tabular}

\section{Discussion:}

Table (1) results reveal statistically significant differences between injured knee and uninjured knee in pre measurement for all research variables towards the uninjured knee ( $\mathrm{Z}$ ranged between -2.611 and -2.652 and ranged between 0.008 and 0.009 ). Researchers return this to that injury and surgical intervention reduce mechanical sensory receptors efficiency, which in turn lead to sense deterioration of knee position and motion with high degradation of neuromuscular functions. This is in line with Zech et al (2009) study results, which indicated that mechanical sensory receptors in knee cartilage cease to function because of injury or surgical intervention.

Table (3) results reveal difference between pre and post mechanical sensory receptors measurement for injured knee with improvement ratio $63.35 \%$ towards post measurement. Table (6) reveals that differences between post mechanical sensory receptors measurements for injured and uninjured knee are nor statistically significant. Researchers attribute this to proposed rehabilitative program and its balance, muscle strength, plyometric exercises increased efficiency of mechanical sensory receptors, neuromuscular abilities, and sense ability of knee position, and motion, so all rehabilitative programs after joint surgery intervention, especially for knee joint, should include exercises to recover motor reception and neuromuscular abilities.

The superiority of post measurement over pre measurement of mechanical sensory receptors variable make first hypothesis accepted.

Table (1) results reveal statistically significant differences between injured knee and uninjured knee in pre measurement in range of motion, front and back muscle strength and balance variables towards the uninjured knee.

Table (3) results reveal difference between pre and post range of motion (flexion and extension) measurements for injured knee with improvement ratio $(55.82 \%$ and $87.48 \%$ ) respectively towards post measurement

The superiority of post measurement over pre measurement of range of motion (flexion and extension) variables make second hypothesis accepted.

Table (3) results reveal difference between pre and post muscle strength (front and back) measurements for injured 
knee with improvement ratio (429.83\% and $506.54 \%$ ) respectively towards post measurement

The superiority of post measurement over pre measurement of muscle strength (front and back) variables make third hypothesis accepted.

Table (3) results reveal difference between pre and post balance measurements for injured knee with improvement ratio $67.83 \%$ towards post measurement.

The superiority of post measurement over pre measurement of balance variable make fourth hypothesis accepted.

\section{Conclusions}

1- The proposed rehabilitative program has a positive effect on mechanical sensory receptors variable.

2- The proposed rehabilitative program has a positive effect on range of motion variable.

3- The proposed rehabilitative program has a positive effect on muscle strength variable for muscles work $n$ knee joint.

\section{Recommendations:}

1- Using the proposed rehabilitative program as a guide during rehabilitation after knee cartilage chondrectomy.

2- It is necessary to continue muscle strength exercises, especially for back muscles during competition period.

3- It is necessary to merge muscle strength and balance exercises using wiggle boards and trampoline during implementation of rehabilitative programs after surgery interventions

4- It is necessary to perform plyometric exercises with different intensities (considering gradation) before return to sport practice.

\section{References}

1- Abdelfattah, H. N. (2007). The effectiveness of a suggested rehabilitative exercise program for the prevention of front cruciate ligament surgery in students of physical education faculty, Al Azhar University.

2- Alawadly, A. (2006). The new in natural therapy and athletic injury. Cairo, Dar Alfekr Alarabi.

3- Bakry, M. K, (2000). Athletic injuries and modern rehabilitation, Cairo, Dar Elnasher Centre.

4- Briggs, C., Sandor, S \& ,.Keninan, M. (1995). The knee. In M. Zuluaga, C. Briggs \& ,S. Carlisle (Eds.) ,Sports physiotherapy: Applied science and practice .London, UK: Churchill Livingstone.

5- Harner, C \& ,.Navarro, R. (1998). Knee cartilage. In M. Safran, D. McKeag \& ,C. Van (Eds.),Manual of sports medicine (pp. 440-447). Philadelphia, PA: LippincottRaven.

6- Kaminski, T. W. (2003). Effect of strength and proprioception training on eversion to inversion strength ratios in subjects with unilateral functional ankle instability. British Journal of Sports Medicine, 37(5), 410415. doi:10.1136/bjsm.37.5.410

7- Lupescu, L., Acsinte, A., Alexandru, E \& Milon, A. (2010). Improving ankle and knee joint stability: Proprioceptive balancefit discs drills.Dartford, UK: Xlibris.

8- Ryad, O. \& Abdelraheem, N. (2001). Assessment and motor rehabilitation of the handicapped, Cairo, Dar Alfekr Alarabi.

9- Yehia, M. \& Zaghlol. I. (2004). Athletic Injuries and its Practices, Egypt, Banha.

10- Zech, A., Hübscher, M., Vogt, L., Banzer, W., Hänsel, F., \& Pfeifer, K. (2009). Neuromuscular training for rehabilitation of sport injuries: A systematic review.Medicine \& Science in Sports \& Exercise, 41(10), 1831-1841. doi:10.1249/mss.0b013e3181a3cf0d 